\title{
STIGMA NEGATIF BAHASA KORUPSI \\ DALAM PEMBERITAAN MEDIA MASSA
}

\author{
Dadang S. Anshori \\ FPBS, Universitas Pendidikan Indonesia \\ email: dadanganshori@upi.edu
}

\begin{abstract}
Abstrak
Penelitian ini bertujuan memberikan gambaran pemakaian bahasa korupsi di media massa sebagai stigma negatif dan terjadinya dekonstruksi makna korupsi yang disebabkan oleh variasi penggunaan bahasa. Dalam analisis bahasa fungsional, pemakaian kosakata dan kalimat yang ditulis di media massa menggambarkan realitas sosial sesungguhnya. Penelitian ini menggunakan pendekatan kualitatif dengan metode deskriptif analitis. Korpus penelitian ini adalah bahasa (kosakata) korupsi yang digunakan majalah Tempo selama 20 edisi yang bertajuk tentang korupsi. Data yang terkumpuldiklasifikasikan dan dianalisis sesuai dengan konteks penggunaannya. Hasil penelitian menunjukkan bahwa majalah Tempo menggunakan kosakata yang bermakna korupsi dalam beragam jenis, terdiri atas 47 kata dan 88 frasa. Hasil analisis sebagai berikut. (1) Luasnya penggunaan kosakata korupsi menggambarkan beragamnya prilaku korupsi yang terjadi di tengah masyarakat. (2) Kata korupsi banyak digunakan dalam bentuk lain, seperti idiom yang bermakna pejoratif dan stigmatisasi. (3) Kata korupsi ditulis dalam bentuk metafora untuk menggambarkan prilaku korupsi dengan makhluk atau benda lain yang memiliki karakter jahat dan bermakna hukuman sosial. (4) Konteks yang ditampilkan lebih pada bahwa korupsi merupakan kejahatan yang merugikan negara dan rakyat.
\end{abstract}

Kata kunci: hukuman sosial, korupsi, kontruksi, stigmatisasi, diksi, ragam makna

\section{NEGATIVE STIGMA OF THE LANGUAGE OF CORRUPTION IN THE MASS MEDIA NEWS}

\begin{abstract}
This study aims to provide an overview of the use of the language of corruption in the mass media as a negative stigma and the deconstruction of the meaning of corruption caused by variations in language use. In the analysis of functional language, the use of vocabulary and sentences written in the mass media describes the social reality. The study used the qualitative approach with the descriptive analytical method. The corpus was the language (vocabulary) of corruptionused by Tempo magazine for 20 editions focusing on corruption. The collected data were classified and analyzed according to the context of the use. The results showthat Tempo magazine used vocabulary meaning corruption in various types, consisting of 47 words and 88 phrases. The results are as follows. (1) The extent of the use of the vocabulary of corruption illustrates the variety of corrupt behaviors in our society. (2) The wordcorruptionis widely used in other forms, such as idioms with pejorative
\end{abstract}


and stigmatization meanings. (3) The word corruption is written in the form of a metaphor to describe corrupt behaviors with other creatures or things that have evil characters and mean social punishment. (4) The context shown is more on the fact that corruption is a crime that harms the state and the people.

Keywords: social punishment, corruption, construction, stigmatization, diction, variety of meanings

\section{PENDAHULUAN}

Maraknya tindakan korupsi yang dilakukan para elite pemerintahan mengantarkan Indonesia menjadi negara darurat korupsi (Kompas, 2018). Berbagai modus dan praktik untuk korupsi semakin variatif dan tidak kehabisan gagasan. Tindakan hukum formal terhadap prilaku koruptif seperti tidak pernah jera bahkan ada kecenderungan korupsi menjadi sebuah budaya birokrasi Indonesia (Pinandito, 2009). Dimensi dan episentrumnya pun semakin meluas mulai dari birokrasi pemerintah hingga lembaga keagamaan seperti pesantren (Haryanto, 2010). Hukum positif-formal seperti tidak dapat berbuat banyak menghilangkan kejahatan luar biasa (extra-ordinary crime) ini, bahkan rekomendasi dan fatwa lembaga keagamaan tentang haramnya korupsi dan hukuman mati bagi koruptor pun seperti tak dipedulikan (Rofii, 2015). Lembaga penegak hukum berlomba dengan munculnya kasus-kasus baru yang tidak kalah mengerikan. Pendekatan hukum formal ini tidak akan sepenuhnya menyelesaikan prilaku koruptif, karena korupsi menjelma menjadi penyakit mental manusia. Untuk itu, diperlukan penguatan tindakan sosial yang dapat menghukum pelaku dari aspek sosial dan moral kemasyarakatan. Dengan cara ini diharapkan akan terbentuk perasaan takut terasing dan terusir secara sosial.
Salah satu institusi yang berperan dalam penegakan moral sosial adalan pers melalui pemberitaannya. Pada tahap tertentu pers bertindak sebagai lembaga hukum sosial (trial by the press). Melalui gaya jurnalistik investigatif, misalnya media bahkan lebih dulu "menegakkan hukum" sebelum para penegak hukum melakukan tindakan hukum kepada para koruptor. Beberapa kasus diusut hukum formal setelah media memberitakannya. Apresiasinya ini ditunjukkan pula masyarakat dalam bentuk melaporkan kasus korupsi kepada media bukan kepada aparat hukum. Peran pers ini bahkan sejak masa Orde Lama dan Orde Baru telah menjadi lembaga yang mengawasi tindak korupsi melalui berbagai pemberitaannya sekalipun mendapatkan tekanan dari rezim penguasa (Padiatra, 2015). Pers menggunakan kekuatan bahasa dalam menerjemahkan kondisi dan realita yang ditangkapnya. Secara umum, media massa menggunakan bingkai sikap mendukung dalam pemberantasan korupsi. Dalam penelitian Mardikantoro (2013) tajuk rencana Kompas, Republika, Koran Tempo, Jawa Pos, dan Suara Merde$k a$ bersikap mendukung pemberitaan korupsi. Namun demikian, framing ini tidak berdampak banyak para perubahan prilaku korupsi. Tekanan media yang terus-menerus diharapkan menimbulkan rasa takut berbagai pihak untuk melakukan tindakan korupsi. 
Dalam konteks hukum sosial ini, penggunaan kosakata korupsi tidak hanya dipahami secara ekonomis dan politis dalam dimensi penyelenggaraan negara yang bersih (good and clean governance). Dalam praktiknya, transformasi makna korupsi diciptakan sedemikian rupa terutama berkait dengan citra penyelenggara negara dan pemosisian koruptor. Korupsi sebagai puncak dari citra buruk stigmatisasi dari sebuah perilaku birokrasi menggerus kepercayaan masyarakat terhadap penyelenggara negara yang lalim. Meskipun demikian, akhir-akhir ini makna korupsi semakin degradatif dan menjadi lazim, karena secara faktual sebaran atau spektrum prilaku korupsi yang demikian luas dan korupsi tidak selalu berarti menikmati uang, tetapi dapat berbentuk kesalahan administratif. Melemahnya "spirit" makna bahasa korupsi tersebut mengindikasikan makin longgarnya hukum sosial terhadap koruptor yang berlaku di masyarakat. Apalagi kalau alasan sistem yang menjadi biang terjadinya korupsi semakin massif di tengah masyarakat.

Wacana tentang korupsi di media massa menjadi hal menarik dan seksi dari segi bahasa karena hampir setiap media massa tak henti-hentinya memberitakan soal korupsi. Sebagai sebuah wacana, teks tentang korupsi dapat dikategorikan dalam teks wacana kritis, mengingat secara umum wacana korupsi mengandung konflik yang sarat dengan pertentangan, terutama pihak yang melawan korupsi (diskursif) (Eriyanto, 2003). Wacana di media massa tidak hanya berfungsi informatif peristiwa atau fenomena korupsi, namun juga memberikan prasangka yang menjadi bagian dari persepsi dan mengkondisi- kan kognisi pembaca melalui berbagai cara penyajian berita tersebut (Mulyana, 2000). Hampir semua ideologi media massa berada di belakang pemberantasan korupsi, sekalipun strategi pemberitaan (redaksional) disajikan dalam beragam cara (Mardikantoro, 2013).

Penggunaan kosakata korupsi dilakukan untuk berbagai kepentingan media massa. Kosakata korupsi juga digunakan untuk berbagai bidang di luar birokrasi yang ada. Secara semantis, kosakata korupsi sudah mendapatkan perluasan makna, melalui beragam bentukan: majasisasi dan idiomisasi. Perluasan pemaknaan ini berimplikasi pada pelebaran fungsi kosakata korupsi dan pada gilirannya konstruksi makna dan efeknya pun akan berbeda. Keragaman konstruksi makna akan menarik dikaji, terutama stigmatisasi sebab setiap penggunaan kosakata korupsi mensyaratkan hadirnya objek atau subjek pemberitaan: koruptor. Dalam KBBI (2008: 1340) stigma diartikan sebagai ciri negatif yang menempel pada pribadi seseorang karena pengaruh lingkungannya. Dalam konteks penelitian ini, stigmatisasi dapat dipahami sebagai sebuah proses penegatifan seseorang karena korupsi yang dilakukannya. Dalam suasana euforia reformasi, seseorang yang dikategorikan koruptor akan mendapatkan stigmatisasi buruk di tengah sosial masyarakat. Di pihak lain, media berperan menjadi "lembaga hukum sosial" yang secara langsung atau tidak langsung dapat mendeskreditkan objek yang diberitakan. Pesan terhakimi ini tercipta karena media massa secara berulang membangun citra koruptor sebagai persona yang buruk secara sosial. Dalam kaitan ini, 
perluasan penggunaan kosakata korupsi memungkinkan terjadinya perluasan hukum dan makna sosial yang ada di masyarakat terhadap kata-kata yang sinonimis dengan kata korupsi. Pada satu sisi hal ini menunjukkan keberhasilan media massa dalam menyosialisasikan kata-kata baru versi media, namun di pihak lain, kosakata korupsi menjadi kata yang tidak sederhana maknanya. Demikian pula, persepsi di masyarakat tidak hanya tertuju pada kosakata korupsi, tetapi kosakata lain yang sepadan yang diperkenalkan pada media massa.

Pemikiran di atas, menegaskan pentingnya mengkaji konstruksi dan ragam makna yang membangun stigmatisasi dalam pemberitaan media massa sebagai hukum sosial. Dalam penelitian ini, Tempo merupakan media yang menarik untuk dikaji, mengingat dua hal penting, yakni pemberitaan Tempo merupakan pemberitaan dengan gaya penulisan feature dan berjenis berita investigasi yang konsisten memberitakan kasus korupsi. Kedua, Tempo merupakan media yang telah banyak berkontribusi pada pengembangan bahasa Indonesia di media massa. Posisi Tempo juga sebagai pelopor bahasa Indonesia jurnalistik dan mendapatkan beberapa penghargaan sebagai media yang menggunakan bahasa Indonesia dengan baik. Tingkat kreativitas berbahasa yang tinggi para redaktur Tempo, akan menyebabkan keragaman penggunaan diksi korupsi juga akan semakin variatif.

Pengkajian terhadap bahasa korupsi yang dikonsumsi secara massif oleh pengguna bahasa, dalam analisis wacana kritis, dapat menggunakan pendekatan politik yang terbuka, bertu- juan untuk menyingkap ideologi yang implisit maupun eksplisit yang tersaji dalam bahasa yang jelas (Wray dkk, 1998). Konsep dasar wacana kritis ini dapat diperoleh melalui beberapa pemikir seperti van Dijk (1980), Kress (1984), Gee (1999), Fairclough (2003), Heracleous (2006), De Fina, Schiffrin dan Bamberg (2006), dan lain-lain. Masing-masing tokoh ini memberikan penekanan pada aspek-aspek yang menjadi fokus kajian sesuai dengan pendekatan yang digunakan, termasuk unsur linguistik sebagai instrumen dasar analisis.

Heracleous (2006) menjelaskan bahwa analisis wacana lebih merupakan sebuah instrumen (alat yang bekerja) dalam teori organisasi, sosiologi, dan studi sastra, bukan sebuah metode positivis dalam mencari aturan-aturan umum yang aplikatif. Analisis wacana lebih merupakan sebuah pendekatan yang menekankan aspek makna dengan cara menghubungkan sebuah teks dalam konteks yang utuh dan konteks sosial. Oleh karena itu, wacana tidak akan bermakna tanpa kehadiran konteksnya.

Keterjalinan antara kajian bahasa dengan korupsi terdapat pada muara karakter moral pengguna bahasa. Bahkan korupsi tidak hanya terjadi dalam pengertian ekonomis, tetapi juga dalam pemakaian bahasa (korupsi bahasa). Prilaku ini tercermin dari penggunaan bahasa yang tidak mengindahkan aturan main berbahasa dengan penalaran yang sengkarut. Praktik ini biasanya dilakukan oleh pihak yang menghegemoni dan mendominasi masyarakat bahasa (Kalitjernih, 2011). Dalam konteks ini moralitas berbahasa relevan dengan moralitas bernegara. 


\section{METODE}

Penelitian ini merupakan penelitian kualitatif dengan pendekatan kritis (Mulyana, 2001, Moleong, 2002). Pendekatan ini memungkinkan digunakan dalam menangkap fenomena kekinian yang terdapat dalam pemberitaan media massa. Data bahasa dalam media massa akan lebih mendalam dan dapat diketahui nilai-nilai yang terkandung di dalamnya apabila dihampiri dengan pendekatan ini. Pendekatan ini pun memungkinkan peneliti ikut serta dalam menafsirkan data-data bahasa yang tersirat dan memberi tafsir atas konstruksi konteks dan maksud dari sebuah komunikasi massa tertulis. Data penelitian ini dikumpulkan dengan menggunakan teknik dokumentasi. Data penelitian berupa wacana pemberitaan tentang korupsi yang terbit pada majalah Tempo yang diambil dari 20 edisi majalah Tempo yang bertopik korupsi yang terbit sepanjang tahun 2011. Pemberitaan korupsi yang teridentifikasi data mencakup semua perbuatan korupsi yang diberitakan majalah ini. Data yang terkumpul diseleksi berdasarkan topik korupsi, diklasifikasi berdasarkan pengelompokan kosakata dan frasa korupsi, dianalisis berdasarkan konteks penggunaan bahasa, dan diberi makna secara leksikon maupun kontekstual. Kosakata dan frasa yang dalam konteks bahasa dapat dijadikan representasi dari fakta yang diberitakan (Chaika, 1982). Kosakata dan frasa yang digunakan diasumsikan merupakan pilihan bahasa yang digunakan Tempo untuk menyampaikan fenomena yang diberitakannya sehingga dipandang sebagai ideologi media (Hodge dan Kress, 1993). Langkah berikutnya adalah menafsirkan makna tekstual dan kontekstual (idiomatik) dari masing-masing kosakata dan frasa yang sudah diklasifikasi tersebut sesuai dengan konstruksi pemberitaan.

\section{HASIL DAN PEMBAHASAN Bentuk Bahasa Korupsi}

Penggunaan kosakata di media massa dapat menggambarkan kepentingan media tersebut dan representasi fakta dan peristiwa korupsi (Chaika, 1982; Hodge dan Kress, 1993). Kritik media massa terhadap korupsi telah berlangsung lama, misalnya dilakukan Mochtar Lubis melalui koran yang dipimpinnya, Indonesia Raya (Semma, 2008). Berdasarkan penelusuran terhadap kosakata korupsi yang digunakan majalah Tempo dalam 20 edisi selama tahun 2011, terdapat beragam kosakata yang mengacu pada beberapa kategori, yakni dari aspek jenis kata dapat dikelompokkan ke dalam kategori verba, kategori nomina, dan ketegori ajektif. Berdasarkan ketegori makna, dapat dikelompokkan dua kategori yaitu makna konotatif dan makna denotatif. Sementara itu, berdasarkan penyajian dapat dikategorikan bentuk kata leksikon dan idiomatik. Kosakata korupsi juga disebut tidak hanya berwujud dalam bentuk kata, namun juga dalam bentuk frasa yang ditulis dalam konteks kalimat. Beberapa kata dan frasa akan lebih jelas maknanya apabila dicermati dalam kalimat atau paragraf yang utuh. Oleh karena itu, pemaknaan terhadap kosakata-kosakata yang menggambarkan korupsi tidak hanya dapat dipahami secara leksikal, namun juga secara kontekstual.

Berdasarkan hasil analisis juga ditemukan banyak istilah atau kosakata bermakna korupsi ini merupakan 
sinonim dari kata korupsi itu sendiri. Sinonim digunakan untuk memberikan penjulukan (labeling) terhadap pelaku atau perbuatan korupsi. Dengan cara ini diharapkan terjadi stigmatisasi dan pencitraan yang buruk terhadap pelaku korupsi atau perbuatan korupsi tersebut. Dalam praktiknya, kosakata-kosakata tersebut digunakan secara berulang pada edisi-edisi majalah Tempo yang menjadi subjek penelitian ini.

Sesungguhnya penggunaan kosakata korupsi sudah tergambar dalam media massa sejak masa Orde Lama, dapat dilihat dari tajuk yang ditulis Mochtar Lubis dalam Indonesia Raya. Beragam kosakata sarkasme yang digunakan Mochtar Lubis untuk menyampaikan kritik terhadap praktik korupsi di masa Orde Lama, misalnya kosakata "republik pisang" dan "pengusaha oktopus" yang bersifat ideomatik. Selain itu, kosakata yang digunakan tampak sarkasme dan menunjukkan "kemarahan" seorang Mochtar Lubis, misalnya kosakata "negara garong", "tauke" "penggarongan di siang bolong", "gerombolan kaum koruptor", "bandit", dan "cukongisme" (Anshori, 2018).

Berdasarkan data-data pada masing-masing edisi, tampak bahwa beberapa kosakata dan diksi yang sama digunakan antara satu edisi dengan edisi berikutnya. Selain itu, majalah Tempo juga membuat atau memunculkan kosakata lain dari kosakata korupsi yang merupakan varian dari istilah atau kosakata sebelumnya. Namun demikian, semua kata yang menggambarkan korupsi ini bermakna buruk (pejoratif) sebagaimana kata korupsi itu sendiri. Data-data di atas dapat dikelompokkan pada berbagai karakter pemakaian bahasa, sesuai dengan kepentingan dan maksud yang hendak disampaikan majalah Tempo. Apabila dilihat dari wujud lingual (kata atau frasa) bahasa, diksi yang menggambarkan kosakata korupsi dalam Tempo ditemukan lebih kurang sebanyak 47 kata dan 87 frasa atau sebanyak 134 diksi sebagaimana digambarkan pada tabel 1 .

Berdasarkan tabel 1, apabila dilihat dari aspek wujud bahasa (bentuk lingual), diksi yang menjelaskan korupsi lebih banyak dibangun dalam bentuk frasa dibandingkan dengan kata. Hal ini dimungkinkan terjadi karena frasa lebih banyak memberi pemahaman dan variasi dibandingkan dengan kata. Kata 'uang' misalnya tidak memberi banyak makna, namun apabila dibentuk dalam frasa, maka akan muncul beragam frasa, baik idiomatik maupun atributif, seperti 'uang sogokan', 'uang semir', 'uang jasa', 'uang pelicin', 'uang persahabatan', 'uang muka', dan 'uang haram'. Demikian pula kata 'transaksi' dan 'makelar' dapat dikembangkan dalam bentuk frasa 'transaksi gelap', 'transaksi haram', 'transaksi mencurigakan', 'transaksi ilegal', 'transaksi janggal' dan 'makelar pajak', 'makelar proyek', dan 'makelar anggaran'. Dengan kata lain, kata lebih "sempit" dalam menjelaskan makna korupsi yang dalam praktiknya dilakukan dengan beragam perilaku. Frasa yang digunakan majalah Tempo dapat terdiri atas dua kata atau lebih dengan beragam fungsi atau struktur. Hal ini menandakan bahwa kosakata korupsi dapat dipergunakan secara luas, termasuk dalam struktur keterangan. Penggunaan kata "uang" yang tidak lagi positif diharapkan dapat memberikan catatan moral bahwa uang hasil haram tidak akan memberikan kebaikan bagi pelaku korupsi. Kosakata dalam kon- 
Tabel 1 Kategori Diksi Korupsi

\begin{tabular}{|c|c|c|}
\hline No. & Kategori & Diksi/Kosakata Korupsi \\
\hline 1 & Kata & $\begin{array}{l}\text { 1) bancakan, 2) bandit, 3) bermain, 4) calo, 5) fee, 6) gangsir, } \\
\text { 7) gratifikasi, 8) insentif, 9) imbalan, 10) jatah, 11) jualan, 12) } \\
\text { kebocoran, 13) kongkalikong, 14) komisi, 15) kakerlak, 16) kiriman, } \\
\text { 17) kolusi, 18) kejahatan, 19) kerugian, 20) makelar, 21) mafioso, } \\
\text { 22) menggarong, 23) manipulasi, 24) menyogok, 25) mengerek, 26) } \\
\text { menyalahgunakan, 27) menggerogoti, 28) nepotisme, 29) ongkos, } \\
\text { 30) operasi, 31) patgulipat, 32) pelicin, 33) perpatronan, 34) } \\
\text { perkoncoan, 35) perampokan, 36) pengisapan, 37) penyelewengan, } \\
\text { 38) penyimpangan, 39) persekongkolan, 40) rasuah, 41) rezeki, 42) } \\
\text { sogokan, 43) suap, 44) skandal, (45) setoran, 46) selingkuh, 47) upeti }\end{array}$ \\
\hline 2 & Frasa & $\begin{array}{l}\text { 1) apel washington, 2) apel malang, 3) bau busuk, 4) bau bacin, 5) bau } \\
\text { amis, 6) biaya komitmen, 6) bunker korupsi, 7) bursa pasal, 8) bagi- } \\
\text { bagi anggaran, 9) buka jasa, 10) commitment fee, 11) calo anggaran, } \\
\text { 12) cek haram, 13) dana ilegal, 14) dana gelap, 15) duit haram, 16) } \\
\text { duit sebakul, 17) duit kotor, 18) duit tak halal, 19) celengan buncit, } \\
\text { 20) episentrum korupsi, 21) fee proyek, 22) gangsir anggaran, 23) } \\
\text { gerombolan penjahat, 24) investasi awal, 25) jasa pengawalan, 26) } \\
\text { jatah anggaran, 27) jatah komisi, 28) kotak sumbangan, 29) ladang } \\
\text { emas, 30) makelar anggaran, 31) mengawal anggaran, 32) mengijon } \\
\text { proyek, 33) mengatur permainan, 34) meraup untung, 35) makelar } \\
\text { pajak, 36) menyalahgunakan jabatan, 37) mata pencaharian, 38) } \\
\text { memperjualbelikan kuota, 39) mengais rezeki, 40) menggangsir } \\
\text { uang publik, 41) memperkaya diri, 42) mafia pajak, 43) ongkos } \\
\text { politik, 44) ongkos komitmen, 45) praktek haram, 46) penggelapan } \\
\text { dana, 47) pengelembungan biaya, 48) pelahap proyek, 49) percaloan } \\
\text { anggaran, 50) politik uang, 51) perdagangan pengaruh, 52) para } \\
\text { pencuri, 53) praktek tak terpuji, 54) praktek kotor, 55) percaloan } \\
\text { izin, 56) penyimpangan tender, 57) pencurian uang publik, 58) } \\
\text { penggelapan APBD, 59) pencucian uang, 60) rekening gendut, 61) } \\
\text { rekening jumbo, 62) rekening mencurigakan, 63) rekayasa anggaran, } \\
\text { 64) setoran gelap, 65) syahwat melahap dana, 66) skenario jahat, 67) } \\
\text { success fee, 68) sarang penyamun, 69) sangu uang, 70) skandal kakap, } \\
\text { 71) transaksi mencurigakan, 72) transaksi gelap, 73) transaksi haram, } \\
\text { 74) transaksi janggal, 75) tanda terima kasih, 76) tarif sedekah, 77) } \\
\text { tambang penghasilan, 78) uang semir, 79) uang haram, 80) uang } \\
\text { sogok, 81) uang muka, 82) uang pelicin, 83) uang jasa, 84) uang } \\
\text { persahabatan, 85) uang lelah, 86) umpan-umpan, 87) ucapan terima } \\
\text { kasih }\end{array}$ \\
\hline
\end{tabular}

teks ini menggambarkan bagaimana moralitas koruptor (Kalidjernih, 2011). Baik kata maupun frasa apabila dilihat dari kesamaan makna (sinonim) da- pat dikelompokkan ke dalam struktur atau fungsi subjek, predikat, objek, dan keterangan. Namun demikian, kategori fungsi ini merujuk pada prilaku 
yang sama: korupsi. Khusus diksi yang merujuk pada subjek (pelaku), kata atau frasa dapat berimplikasi dalam memberikan stigmatisasi dan pencitraan buruk secara sosial. Stigmatisasi dilakukan untuk memberikan efek jera atau efek malu bagi pelakunya. Dengan demikian, diharapkan prilaku atau perbuatan buruk tersebut dapat dihindari oleh setiap orang.

Berdasarkan hal di atas, jelas stigmatisasi bagi pelaku dilakukan majalah Tempo. Hal ini mengindikasikan keberpihakan Tempo terhadap pemberantasan dan penegakkan hukum masalah korupsi. Melalui struktur dan ekspresi bahasa, keberpihakan tersebut tergambar secara jelas (Mardikantoro, 2014). Tempo menyebut koruptor dengan beberapa kosakata dengan tingkatan efek stigma yang berbeda. Label-label tersebut semuanya mengandung makna pejoratif bagi para penyandangnya.

1. Stigma yangjauh lebih keras (kasar): 'bandit', 'calo', 'kakerlak', 'makelar', 'mafioso', 'calo anggaran', 'gangsir', 'gerombolan penjahat', 'makelar anggaran', 'makelar pajak' 'mafia pajak', 'pelahap proyek', dan 'para pencuri'.

2. Stigma sarkasme (disfemisme) dari koruptor dengan sebutan calo, makelar, mafia, penjahat, dan pencuri merupakan bentuk kejahatan yang paling konkret dan musuh paling nyata dalam masyarakat.

Berdasarkan struktur predikat, kata korupsi dikembangkan dalam banyak frasa yang semuanya menggambarkan prilaku yang dilakukan oleh koruptor. Kata-kata berikut memberikan gambaran betapa jahatnya prilaku koruptor dalam menyedot uang rakyat: 'bancakan', 'bermain', 'gratifikasi', 'kebocoran', 'kongkalikong', 'kolusi', 'mengerek', 'menyalahgunakan', 'menggerogoti', 'nepotisme', 'kejahatan', 'kerugian', 'menggarong', 'manipulasi', 'menyogok', 'operasi', 'patgulipat', 'perpatronan', 'perkoncoan', 'perampokan', 'pengisapan', 'penyelewengan', 'penyimpangan', 'persekongkolan', 'skandal', 'setoran', dan 'selingkuh'. Kata 'bancakan' memberi makna bahwa korupsi dilakukan secara bersamasama. Kata ini sejajar dengan 'perpatronan', 'perkoncoan', 'patgulipat', dan 'persekongkolan'.

Sementara itu, kata 'penyelewengan' dan 'penyimpangan' memberikan pemahaman bahwa perilaku korupsi bukan pekerjaan yang benar dan dibenarkan. Perilaku menyeleweng dan menyimpang seharusnya dipandang sebagai anomali dalam masyarakat.

Sebagai objek, korupsi digambarkan dengan kata-kata yang menjelaskan uang (benda) yang dikorupsi atau hasil korupsi (korupsian). Kata lain dari hasil korupsi ini ditulis majalah Tempo dengan kata-kata yang sangat keras (kasar): fee, ongkos, jatah, insentif, komisi, pelicin, imbalan, jualan, kiriman, rasuah, rezeki, upeti, sogokan, suap, apel washington, apel malang, biaya komitmen, commitment fee, cek haram, dana ilegal, dana gelap, duit haram, duit sebakul, celengan buncit, fee proyek, investasi awal, jatah anggaran, jatah komisi, kotak sumbangan, ladang emas, mata pencaharian, duit tak halal, ongkos politik, ongkos komitmen, duit kotor dan lain-lain. Kata 'upeti' mengingatkan kita pada masa pemerintahan kolonial Belanda yang selalu menarik 'upeti' dari kaum pribumi. Dari segi ini 'upeti' menunjukkan bahwa bangsa kita sesungguhnya belum merdeka, karena 
harus membayar 'upeti' kepada bangsa sendiri. Kata 'dana ilegal', 'dana gelap' atau 'duit haram' memberikan pemahaman bahwa korupsi merupakan kegiatan 'hitam' yang diharamkan baik oleh agama maupun hukum dan nilai sosial. Kosakata 'haram' menunjukkan bahwa hukum terhadap korupsi bukan hanya diberikan secara sosial, tetapi juga agama. Oleh karena itu, hukuman kepada koruptor bukan hanya berbentuk hukuman moral-sosial, namun juga hukuman nilai agama (Haryanto, 2010) dan bahkan dengan sindiran syair lagu (Kurniawan, 2009).

Secara fungsi ajektif, korupsi dalam diwakili oleh idiom 'bau bacin', 'bau busuk' atau 'bau amis'. Korupsi merupakan pekerjaan yang menyebarkan bau kepada pelaku dan keluarganya. Kata sifat ini hendak menunjukkan bahwa prilaku korupsi seharusnya lebih memalukan daripada kejahatan lainnya. Akibatnya, rasa malu jauh lebih besar daripada rasa berdosa dirasakan oleh pelakunya. Banyak pelaku korupsi yang tidak dapat bermasyarakat atau bahkan tidak diterima di masyarakat karena sudah mendapatkan stereotif buruk di tengah masyarakat.

\section{Makna dan Stigma Negatif Bahasa Korupsi}

Berdasarkan makna yang dikandung, kosakata atau diksi korupsi dapat dikelompokkan ke dalam makna idiomatif, leksikon, metafora, eufemisme, dan disfemisme. Hal ini sesuai dengan ketajaman kritik atau pemberitaan yang disampaikan media (Anshori, 2018; Mardikantoro, 2014). Pengelompokkan ini hanya didasarkan pada kecenderungan makna yang dibangun dalam kosakata-kosakata yang dihasilkan. Se- sungguhnya mungkin akan dihasilkan kategori pengelompokkan makna yang lainnya yang tidak dilakukan dalam analisis di sini. Berdasarkan kategori di atas, makna diksi korupsi dapat digambarkan pada tabel 2 .

Berdasarkan kategori makna di tabel 2, makna idiomatik tercermin dari penggunaan kata-kata yang menunjukkan makna yang bukan sesungguhnya (konotatif). Kata-kata ini digunakan majalah Tempo untuk memberikan gambaran korupsi sebagai prilaku yang memiliki banyak dimensi mengingat luasnya spektrum korupsi (Haryanto, 2010). Makna idiomatik tercermin dari kata-kata: bermain, jualan, kebocoran, operasi, mengerek, pelicin, rezeki, selingkuh, bau busuk, bau bacin, bau amis, biaya komitmen, buka jasa, cek haram, dana gelap, duit haram, duit kotor, jasa pengawalan, investasi awal, kotak sumbangan, ladang emas, mengawal anggaran, mata pencaharian, mengais rezeki, ongkos komitmen, praktek haram, penggelapan dana, perdagangan pengaruh, praktik kotor, penggelapan APBD, setoran gelap, transaksi gelap, tanda terima kasih, uang pelicin, tambang penghasilan, uang semir, uang haram, uanglelah, umpan-umpan, uang persahabatan dan lain-lain. Dalam kata 'bermain' kita memahami bahwa korupsi terjadi karena adanya 'permainan' dari pihak-pihak tertentu dalam mengalokasikan anggaran negara atau menggunakan anggaran negara. Oleh karena itu korupsi berkait dengan persoalan kekuasaan negara (Pinandito, 2009; Semma, 2014). Menggembungkan anggaran, misalnya, disebut majalah Tempo dengan kosakata 'mengerek' anggaran. Selain itu, terdapat idiomatik 'jualan' yang maknanya hampir sama dengan 
Tabel 2. Kategori Makna Diksi Korupsi

\begin{tabular}{|c|c|c|}
\hline No. & Kategori & Diksi/Kosakata Korupsi \\
\hline 1 & Idiomatik & $\begin{array}{l}\text { bermain, jualan, kebocoran, operasi, mengerek, pelicin, rezeki, } \\
\text { selingkuh, bau busuk, bau bacin, bau amis, biaya komitmen, buka } \\
\text { jasa, cek haram, dana gelap, duit haram, duit kotor, jasa pengawalan, } \\
\text { investasi awal, kotak sumbangan, ladang emas, mengawal anggaran, } \\
\text { mata pencaharian, mengais rezeki, ongkos komitmen, praktek } \\
\text { haram, penggelapan dana, perdagangan pengaruh, praktek kotor, } \\
\text { penggelapan APBD, setoran gelap, transaksi gelap, tanda terima } \\
\text { kasih, uang pelicin, tambang penghasilan, uang semir, uang haram, } \\
\text { uang lelah, umpan-umpan, uang persahabatan, mengatur permainan, } \\
\text { transaksi haram, commitment fee, success fee, menyalahgunakan jabatan, } \\
\text { pelahap proyek, ucapan terima kasih }\end{array}$ \\
\hline 2 & Metafora & $\begin{array}{l}\text { apel washington, apel malang, bunker korupsi, bursa pasal, duit } \\
\text { sebakul, celengan buncit, rekening gendut, pencucian uang, rekening } \\
\text { jumbo, sarang penyamun, skandal kakap }\end{array}$ \\
\hline 3 & Leksikon & $\begin{array}{l}\text { bancakan, fee, gratifikasi, insentif, jatah, kongkalikong, kiriman, } \\
\text { kolusi, kejahatan, kerugian, manipulasi, menyogok, menggerogoti, } \\
\text { nepotisme, ongkos, patgulipat, perpatronan, perkoncoan, } \\
\text { persekongkolan, rasuah, sogokan, suap, skandal, bagi-bagi anggaran, } \\
\text { dana ilegal, episentrum korupsi, fee proyek, jatah anggaran, jatah } \\
\text { komisi, meraup untung, memperjualbelikan kuota, memperkaya } \\
\text { diri, ongkos politik, pengelembungan biaya, politik uang, rekayasa } \\
\text { anggaran, skenario jahat, sangu uang, transaksi janggal, uang sogok }\end{array}$ \\
\hline 4 & Eufemisme & $\begin{array}{l}\text { tarif sedekah, uang jasa, duit tak halal, praktek tak terpuji, } \\
\text { penyimpangan tender, rekening mencurigakan, uang muka, imbalan, } \\
\text { komisi, menyalahgunakan, penyelewengan, penyimpangan, transaksi } \\
\text { mencurigakan }\end{array}$ \\
\hline 5 & Disfemisme & $\begin{array}{l}\text { gerombolan penjahat, mafia pajak, percaloan anggaran, syahwat } \\
\text { melahap dana, uang sogok, pencurian uang publik, para pencuri, } \\
\text { mengijon proyek, makelar anggaran, makelar pajak, gangsir } \\
\text { anggaran, calo anggaran, menggangsir uang publik, percaloan izin, } \\
\text { bandit, calo, gangsir, setoran, upeti, kakerlak, makelar, mafioso, } \\
\text { menggarong, perampokan, pengisapan }\end{array}$ \\
\hline
\end{tabular}

'buka jasa', dan 'perdagangan pengaruh', yaitu menggunakan kekuasaan untuk mencari kekayaan sebanyak-banyaknya (memperkaya diri). Kata 'gelap' sebagai pokok idiomatik 'setoran gelap', 'transaksi gelap', 'penggelapan dana', dan 'penggelapan APBD', yang menunjukkan makna sebuah kegiatan korupsi, bukan kegiatan di ruang gelap. Makna idiomatik korupsi berkait dengan kekuasaan negara yang diselewengkan penyelenggara yang tidak amanah (Semma, 2014).

Sementara itu, beberapa kosakata korupsi dapat dimaknai secara metafora: apel washington, apel malang, bun- 
ker korupsi, bursa pasal, duit sebakul, celengan buncit, rekening gendut, pencucian uang, rekening jumbo, sarang penyamun, skandal kakap. Frasa 'apel malang' dan 'apel washington' digunakan untuk menunjukkan uang rupiah dan uang dolar. Uang diumpamakan dengan buah-buahan. Sementara itu, korupsi juga diumpamakan dengan tempat persembunyian, sehingga digunakan kata 'bunker korupsi'. Frasa 'celengang buncit' 'rekening gendut', 'rekening jumbo', dan 'duit sebakul' merupakan metafora dari uang korupsi dalam jumlah banyak. Sementara itu lembaga DPR diumpamakan sebagai 'sarang penyamun' (tempat para pencuri mencari barang jarahannya). Praktik yang sering dilakukan para koruptor untuk menghilangkan modus korupsi adalah dengan menggunakan uang hasil korupsi untuk usaha ekonomi atau asuransi. Kegiatan tersebut diumpamakan sebagai 'pencucian uang'. Makna metafora berkait dengan permainan bahasa untuk sebuah kepentingan kekuasaan sehingga makna yang dibentuk hanya pihak-pihak tertentu yang mengetahui (Kress, 1984).

Dalam praktik jurnalistik, majalah Tempo juga menggunakan eufemisme untuk menyebut kegiatan korupsi. Majalah Tempo menggunakan kata-kata: tarif sedekah, uang jasa, duit tak halal, praktek tak terpuji, penyimpangan tender, rekening mencurigakan, uang muka, imbalan, komisi, menyalahgunakan, penyelewengan, penyimpangan, dan transaksi mencurigakan. Kata atau frasa ini tampak lebih halus dan santun, padahal makna yang dimaksud sama dengan makna 'korupsi'. Dalam beberapa berita, karena menyangkut pihak yang memahami agama, Tem- po menyebut kegiatan korupsi sebagai 'tarif sedekah'. Dalam kegiatan birokrasi apalagi dalam soal perizinan, antara upeti, jatah, komisi, dan sedekah sulit dibedakan, namun semuanya bermuara pada kata 'korupsi'. Frasa 'uang jasa', 'duit tak halal', dan 'praktik tak terpuji' merupakan bentuk kesantunan dari kegiatan korupsi. Pada kesempatan lain, majalah Tempo menyebut korupsi sebagai 'duit haram', dan 'praktik haram'. Kata 'menyalahgunakan', 'penyelewengan' dan 'penyimpangan' mempunyai makna yang sama: pelanggaran aturan dan berhubungan dengan kekuasaan. Korupsi terjadi karena ketiga kata tersebut sehingga perilaku koruptor menjadi tidak sesuai dengan aturan. Eufemisme menjadi sebuah praktik berbahasa yang menyembunyikan makna karena budaya feodalisme atau ketidakjujuran (Semma, 2014; Anshori 2018).

Majalah Tempo juga menggunakan kosakata korupsi dengan kata atau frasa yang bermakna disfemisme atau sarkasme, seperti 'gerombolan penjahat', 'mafia pajak', 'percaloan anggaran', 'syahwat melahap dana', 'uang sogok', 'pencurian uang publik', 'para pencuri', 'mengijon proyek', 'makelar anggaran', 'makelar pajak', 'gangsir anggaran', 'calo anggaran', 'menggangsir uang publik', 'percaloan izin', 'bandit', 'calo', 'gangsir', 'setoran', 'upeti', 'kakerlak', 'makelar', 'mafioso', 'menggarong', 'perampokan' dan 'pengisapan'. Kata dan frasa tersebut seharusnya membuat pelaku tersadarkan bahwa betapa masyarakat Indonesia sangat marah dengan perilaku korupsi mereka, sehingga media massa merepresentasikan kemarahan publik dengan bahasabahasa seperti tersebut (Chaika, 1982; 
Mardikantoro, 2014; Anshori 2018). Kata 'bandit', 'calo', 'makelar' sebenarnya tidak layak disandang para koruptor yang umumnya termasuk 'kelas atas' masyarakat Indonesia. Namun, anehnya mereka melupakan bahwa julukan-julukan tersebut akan disematkan kepada pelaku korupsi karena perbuatan tersebut termasuk perbuatan nista. Dengan kata-kata tersebut framing Tempo sangat jelas, bersama-sama rakyat membenci perbuatan korupsi (Mardikantoro, 2014).

\section{SIMPULAN}

Berdasarkan uraian di atas, penelitian ini dapat disimpulkan bahwa luasnya penggunaan kosakata korupsi menggambarkan beragamnya perilaku korupsi yang terjadi di tengah masyarakat kita. Berdasarkan analisis ditemukan sebanyak 47 kata dan 88 frasa yang sinonim dan menggamkan kosakata korupsi. Penggunaan kata korupsi banyak digunakan dalam bentuk lain, seperti idiom yang bermakna pejoratif. Hal ini berarti bahwa makna-makna yang dilahirkan dari kosakata korupsi semua menunjukkan keburukan yang dipahami masyarakat. Stigmatisasi ini diharapkan dapat menyebabkan pelakunya merasa malu dan jera. Kosakata korupsi ditulis dalam pemberitaan Tempo lebih banyak menggunakan metafora untuk menggambarkan prilaku korupsi dengan makhluk atau benda lain yang memiliki karakter jahat. Sementara itu, konteks yang ditampilkan lebih pada bahwa korupsi merupakan kejahatan yang merugikan negara dan rakyat. Korupsi ini ini digambarkan dalam beragam konteks kalimat yang melambangkan beragam perilaku korupsi di berbagai lapisan birokrasi dan dunia politik Indonesia. Apabila mengacu kepada pendapat para ahli bahwa kata dan kalimat menggambarkan realitas, beragam kosakata yang digunakan media menggambarkan mengguritanya praktik korupsi di Indonesia.

\section{UCAPAN TERIMA KASIH}

Tulisan ini terpublikasi atas bantuan banyak pihak. Ucapan terima kasih saya sampaikan kepada pimpinan Universitas Pendidikan Indonesia yang lebih memberikan fasilitas untuk terlaksananya penelitian ini. Demikian pula ucapan terima kasih saya sampaikan kepada pengelola jurnal Litera yang telah bersedia memuplikasikan artikel ini.

\section{DAFTAR PUSTAKA}

Anshori, D. S. 2018. "Bahasa Kritik Mochtar Lubis: Analisis Wacana Kritik Tajukrencana Korupsi Pada Harian Indonesia Raya (1966-1974)". Arkhais, Jurnal Ilmu Bahasa dan Sastra Indonesia, vol 9, (1), 1-11.

De Fina, A., Schiffrin, D. dan Bamberg, M. 2006. Discourse and Identity. Cambrige: Crambrige University Press.

Chaika, E. 1982. Language The Social Mirror. Rowley: Newbury House Publisher, Inc.

Eriyanto. 2003. Analisis Wacana, Pengantar Analisis Teks Media. Yogyakarta: LkiS.

Fairclough, N. 2003. Analysing Discourse, Textual Analysis for Social Research. London: Routledge.

Gee, J. P. 1999. An Introduction to Discourse Analysis, Theory and Method. London: Routledge. 
Haryanto, R. 2010. "Korupsi di Pesantren: Distorsi Peran Kiai Dalam Politik". Jurnal Karsa, vol. XVII, (1), 38-50.

Heracleous, L. 2006. Discourse, Interpretation, Organization. Cambridge: Cambridge University Press.

Hodge, R. dan Kress, G. 1993. Language as Ideology. London: Routledge.

Kalitjernih, F. K. 2011. "Some Notes on the Relationship Between Language Use and Moral Character: A Case of Linguistic Corruption in Indonesia." Jurnal Linguistik Indonesia, vol. 29, (2), 167-184.

Kamus Besar Bahasa Indonesia Pusat Bahasa, Edisi Keempat. 2008. Jakarta: Gramedia.

Kompas. 2018. "Indonesia Darurat Korupsi”, edisi 15 Februari 2018.

Kress, G. 1984. "Linguictic and Ideological Transformations in News Reporting". Dalam Language, Image, Media (Davis, H. dan Walton, P., eds.). England: Basil Blackwell, 1984.

Kurniawan, T. 2009. "Analisis Gaya Bahasa Ironi dan Pesan Moral Lagulagu Slank dalam Album Antikorupsi, Tinjauan Semiotik". Tesis tidak Diterbitkan. Surakarta:Universitas Muhammadiyah Surakarta.

Mardikantoro, H. B. 2014. "Analisis Wacana Kritis pada Tajuk (Anti) Korupsi di Surat Kabar Berbahasa Indonesia". Jurnal Litera, vol. 13, (2), 215-225.

Mulyana, D. 2000. Ilmu Komunikasi, Suatu Pengantar. Bandung: Rosdakarya.Mulyana, D. 2001. Metodologi
Penelitian Kualitatif, Paradigma Baru Ilmu Komunikasi dan Ilmu Sosial Lainnya. Bandung: Rosdakarya.

Moleong, L. J. 2002. Metodologi Penelitian Kualitatif. Bandung: Rosdakarya.

Padiatra, A. M. 2015. "Ketika Pers Bicara Korupsi: Analisis Tajuk Rencana Harian Pedoman pada Awal Orde Baru 1969-1974. Paradigma, Jurnal Kajian Budaya, vol. 5, (2), 1-15.

Pinandito, D. 2009. "Korupsi dalam Tajuk Rencana Mochtar Lubis (Analisis Wacana Kritis Pemikiran Mochtar Lubis tentang Korupsi dalam Tajuk Rencana Harian Indonesia Raya Periode 1968-1974 dalam Buku Tajuk-tajuk Mochtar Lubis di Harian Indonesia Raya Seri 1 dan 2)". Surakarta: FISIP UNS.

Rofii, M. S. 2015. "Hukuman Mati bagi Koruptor: Sebuah Diskursus Mendesak di Masa Kritis". Instinbath, Jurnal Hukum, vol. 12, (1), 1-15.

Semma, M. 2008. Negara dan Korupsi: Pemikiran Mochtar Lubis atas Negara, Manusia Indonesia, dan Prilaku Politik. Jakarta: Yayasan Obor Indonesia.

Van Dijk, Teun A. 1980. Macrostructures An Interdisciplinary Study of Global Structures in Discourse, Interaction, and Cognition. New Jersey: Lawrence Erlbaum Associates.

Wray, A., Trott, $\mathrm{K}$ dan Bloomer A. 1998. Projects in Linguistics, A Practical Guide to Researching Language. London: Arnold. 